\title{
The Role of Leadership in the Talent Management and Employee Retention of Education in Abu Dhabi
}

Hasan Abdulla Al Hammadi

Mohd Asri Bin Mohd Noor

Asso. Prof. Dr., Faculty of Management \& Economics, University of Pendidikan Sultan Idris, Tanjung Malim. Malaysia

\begin{abstract}
The term Talent Management first emerged in 1998. The paper pointed to a major challenge facing large organizations in the U.S. at the time, which was the difficulty of attracting and retaining talented and experienced people especially for senior executive / leadership roles. The Talent Management as identified and mentioned by researchers. In general, these components could be considered as a component of talent retention and leadership, however, they do identify more with one of the main components than the other based on their characteristics Leadership: the talent mind set needs to be embedded throughout the organization, starting with the organization's head (Kehinde 2012). This research is important for academic reason; it helps to provide essential data and enhance ability of the organization to employee retention to longer period. Data were collected by distributing questionnaires to 371 systematic randomly sampled respondents. Data collected were analyzed by using descriptive and inferential statistics. The research showed that The Role of Leadership in The Talent Management and Employee Retention of Education in Abu Dhabi.
\end{abstract}

Keywords: Leadership, Talent Management, Employee Retention, Education

\section{Introduction}

Talent management conclusively plays a great role in guaranteeing enduring representative retention in any organization. Leadership is seen as one of the main point that could upgrade the connection between ability the executives and employee retention, initiative is viewed as exceptionally critical in any organization since it is the leader's practices that are viewed as answerable for demolishing or improving the organization. The organizations directions depend on the style embraced by its pioneers. Since leadership, helps in arranging the organization's directions about the future, its leader's practices and behaviors are the elements that drive their followers or devotees to achieve the goals. Accordingly, followers for the most part pursue their leader's practices when performing their duties (Heravi et al., 2010).

There are different types of leadership such as demographic leadership, transformation leadership, autocratic leadership and many more, (Voon M.C. et al, 2011). Transformational leadership is known to be a very beneficial leadership as it helps to transform ideas and take suggestions from each member.

The relationship between talent management and leadership in any organization is considered as positive relationship, (Irtaimeh \& Khaddam, 2017). Because when the organization takes care of their talent employees and find the qualified leader that can lead to organization growth and increase employee satisfaction and employee retention. The organization will retain the talent employees as well as find more leaders with different styles of leadership.

Leader in the organization helps in talent management; they provide training to new as well as current applicants. They are able to motivate and support employees at every level in organization. Leader inspires its team members for achieving the common goal. They create clear vision for people working in firm and able to drive them towards this. Appropriate Leadership is very essential in organization as it helps in employee retention, which is quite beneficial for business growth and success. The purpose of this is to identify the relationship between talent management, employee retention and leadership. There for the research help to in depth knowledge and information about everything, (McDonnell et al. 2010). 


\section{Problem Statement}

In view of the importance of develop organizations, there are many studies on the talent management, employee retention and leadership on the world. There is many research done on talent management and employee retention on different sectors for example in Ghana, in the Ministry of Roads and Highways, the relationship between talent management and employee retention, but this study is not have moderating leadership, (beatrice nyarkoah, 2016). In addition, in Malaysia in industry sector have be done research the role of talent management and in employee retention (yong pui chee ,2017). According to (Israa Ramadan AlBattrikhi,2016) the research is be done on talent management in IT companies in Gaza. Also in the UAE have many research done in develop talent management such us on public sector in Abu Dhabi Police, (ALmansoori, 2015). Talent management and leadership being adopted by school manager's focus on ensuring organizational commitment of workers. It can be said that workers should convey primary values of institution and ensuring their emotional commitment. Moreover, ensuring that environment and opportunities suitable for workers for developing skills is required for perfect commitment (Linley \& Joseph, 2006). However, a few studies were conducted which dealt with one or two variables. Based on the above, the gap is no previous researches have been done on three variables together on Talent management to decrease Emirati teacher's turnover from Department of Education and Knowledge in Abu Dhabi. Therefore, these three aspects represent a knowledge gap and, hence, this study attempts to fill the above gaps.

\section{Literature review}

In order to understand talent management in education sector, it is necessary to know the meaning of talent management and it's important, (Kehinde, 2012). Talent management as juxtaposed with talent as such which is related to set of processes being concerned to strategic management of talent flow through firm (lles et al. 2011). The phrase used by McKinsey Consultancy Company was "the war for talent" which has focused on concept of "talent" by scholars and practitioners (Lewis \& Heckman, 2006; Lynton \& Beechler, 2012). This is because intense focus on talent is made as it is crucial among all resources for success of enterprise (He, Li, \& Keung Lai, 2011; Huselid, Beatty, \& Becker, 2005). The talent management is mainly originated from performing arts, now it has eventually become powerful strategic force found in universities, businesses, hospitals and government units. After boom identified in UAE in public and private sectors, many firms have initiated plans for meeting their talent needs of future so as to sustain in UAE (Ulrich et. al, 2009). Retaining talents in UAE government sector has been a major challenge for long time. The benefits of implemented talent management strategy mainly include recruitment and retention rates. It is useful as retaining knowledgeable employees leads better source of speedy development of firm (Sigler, 1999). The greatest benefit of talent management is that effect on recruitment and retention of invaluable workers. According to Lalitha, (2012) biggest issue faced by HR in sector education is employee retention.

\section{Research Methodology}

This research adopts a positivism philosophy which is most appropriate for the aim of this research which is to find the relationship between competency mapping, employee engagement, performance management, and career development and employee retention. In line with positivism philosophy, statistical techniques would be used to interpret data collected. This research is based on the basis of pre-existential quantifiable information that can be obtained from different types of employees from various organizations via observation. 


\section{Overview of Conceptual Framework}

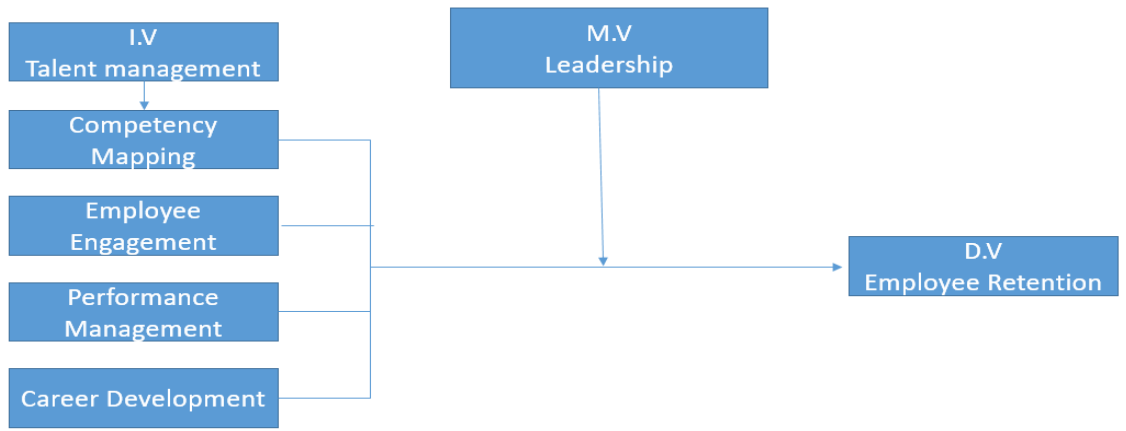

\section{Instruments (Questionnaire)}

The tool that will be used in this research survey questionnaire. It is helps the researcher to get a clear perspective of the research topic. Questionnaire design plays an important role in the entire research.

This survey includes a simple questionnaire that deals with the development of survey report in a more convenient way. There are several steps that have been used for development of the research more genuinely with the help of a simple questionnaire. With the help of simple questionnaire researcher will be able to make the survey more easy understanding.

After revising the previous studies of the subject, the Questionnaire developed for this study designed to be a close-ended type. The questionnaire is finalized in ow section as follows: section A: includes the demographic data of the study sample using six main categories: (Gender, age, Educational Level, Nationality, Years of Experience, location of Abu Dhabi Emirate). Section B include three part the first one consists independent vectors of talent management

\section{Data Analysis \& Result}

In this study, the researcher use correlation method to explore the relationship between quantitative variables and to measure the linking or strength the relationship between all talent management independent variables with employee retention depend variable. To understand the relationship between variable to variable such as increase or decrease. The findings of the present study assist managers in the formulation of effective retention policies using appropriate variables. Regression examination is a type of prescient displaying strategy, which explores the connection between variables. This procedure is utilized for talent management demonstrating and finding the causal impact connection between the factors. For instance, connection between talent management and employee retention is best concentrated through regression. Regression examination is a significant device for demonstrating and investigating information

Regression analysis enables researchers to look at the impacts of factors estimated on various scales. These advantages help economic specialist or information experts or information researchers to avoid and assess the best set of factors to be utilized for developing prescient models.

\begin{tabular}{|c|c|c|c|c|}
\hline No & Research Objectives & Research Questions & Research Hypotheses & Analyses \\
\hline 1 & $\begin{array}{l}\text { R01: To examine the relationship of } \\
\text { competency mapping on employee } \\
\text { retention }\end{array}$ & $\begin{array}{l}\text { RQ1 : Does competency mapping } \\
\text { influence employee retention? }\end{array}$ & $\begin{array}{l}\mathrm{RH} 1: \text { There is a relationship between } \\
\text { competency mapping and employee } \\
\text { retention }\end{array}$ & Correlation \\
\hline 2 & $\begin{array}{l}\text { R02: To examine the relationship of } \\
\text { employee engagement on employee } \\
\text { retention }\end{array}$ & $\begin{array}{l}\text { RQ2: Does employee engagement } \\
\text { influence employee retention? }\end{array}$ & $\begin{array}{l}\text { RH2: There is a relationship between } \\
\text { employee engagement and } \\
\text { employee retention }\end{array}$ & Correlation \\
\hline 3 & $\begin{array}{l}\text { R03: To examine the relationship of } \\
\text { performance management on } \\
\text { employee retention }\end{array}$ & $\begin{array}{l}\text { RQ3: Does performance } \\
\text { management influence employee } \\
\text { retention? }\end{array}$ & $\begin{array}{l}\text { RH3: There is a relationship between } \\
\text { performance management and } \\
\text { employee retention }\end{array}$ & Correlation \\
\hline
\end{tabular}




\begin{tabular}{|c|c|c|c|c|}
\hline 4 & $\begin{array}{l}\text { R04: To examine the relationship of } \\
\text { employee career development on } \\
\text { employee retention }\end{array}$ & $\begin{array}{l}\text { RQ4: Does career development } \\
\text { influence employee retention? }\end{array}$ & $\begin{array}{l}\text { RH4: There is a relationship between } \\
\text { career development and employee } \\
\text { retention }\end{array}$ & Correlation \\
\hline 5 & $\begin{array}{l}\text { R05: To examine the influence of } \\
\text { leadership on the relationship } \\
\text { between talent management and } \\
\text { employee retention. }\end{array}$ & $\begin{array}{l}\text { RQ5: Does leadership moderate } \\
\text { the relationship between talent } \\
\text { management and employee } \\
\text { retention? }\end{array}$ & $\begin{array}{l}\text { RH5: There is a moderating effect of } \\
\text { leadership on the relationship } \\
\text { between talent management and } \\
\text { employee retention }\end{array}$ & Regression \\
\hline
\end{tabular}

After analysis the data the main result finding according to empirical study, that is a significant influence between independent variable (talent management) and dependent variable. The relationship between independent variables and employee retention are positively. The R2 value 0.491 the regression of models was statistically significant. Studies conducted to that talent management have enhancing the employee retention.

\section{References}

[1] Al Mansoori Mansoor, 2015, A Study into the Benefits of Developing Talent Management within the Public Sector: The Case of Abu Dhabi Police General Head Quarters - UAE, http://researchonline.ljmu.ac.uk/id/eprint/4449/1/158256_2015AIMansooriPhD.pdf

[2] Heravi et al., 2011 M. Heravi, M. Blaze, M.T. Sheikhi, I. Hajj YzadhPsychometric questionnaire designed Elder Abuse in the family, Journal of Aging, 15 (15) (2011), pp. 7-21

[3] Huselid, Mark \& Beatty, Richard \& Becker, Brian. (2006). A Players or A Positions? The strategic logic of workforce management. Harvard business review. 83. 110-7, 154.

[4] Iles RA, Davidson M, Taylor NF, O'Halloran P (2011) Systematic review of the ability of recovery expectations to predict outcomes in non-chronic non-specific low back pain. Journal of Occupational Rehabilitation 19: 2540

[5] Irtaimeh, Hani J., Al-Azzam, Zeyad F. \& Khaddam, Amineh A. (2016). Exploring the Impact of Talent Management Strategies and Service Quality on Beneficiaries Satisfaction in Jordan Healthcare Sector: Provider point of ,View. International Journal of Management (IJM), 7(7), 23-38.

[6] Israa ALBattrikhi, 2016, Talent Management Practices as Drivers of Intention to Stay Case Study (IT Companies in the Gaza Strip), retrieve https://www.mobt3ath.com/uplode/book/book-14422.pdf

[7] Kehinde, J. S. (2012). Talent Management: Effect on Organizational Performance. Journal of Management Research, 4(2), 76-88.

[8] Lewis\&Heckman, 2006, talent management, Human Resource Management (139-154), http://isiarticles.com/bundles/Article/pre/pdf/1680.pdf

[9] Linley, P.A., \& Joseph, S. (2006). Positive and negative aspects of disaster work. Journal of Loss and Trauma, $11,229-245$

[10] Lynton, N. ve Beechler, S. (2012), Using Chinese managerial values to win the war for talent, Asia Pacific Business Review, 18(4), 567-585

[11] MacDonald, M. and lyer, S. 2011. Skillful Means. The Challenges of China's

[12] Encounter with Factory Farming. Brighter Green. [online] Available from

[13] http://www.brightergreen.org/files/brightergreen_china_print.pdf [accessed 20

[14] June 2011

[15] Sigler, K. (1999), "Challenges of employee retention", Management Research News, Vol. 22 No. 10, pp. 1-5. https://doi.org/10.1108/01409179910781823

[16] Ulrich, D., Brockbank, W. \& Johnson, D., 2009. The Role of Strategy Architect in the

[17] Strategic HR Organization. People \& Strategy, 32(1), pp.24-31.

[18] Voon et al. / International Journal of Business, Management and Social Sciences, Vol. 2, No. 1, 2010, pp. 2432

[19] Yong pui chee, 2016, the role of talent management in employee retention, retrieve http://eprints.utar.edu.my/2488/1/Thesis_Final_Copy_(1).pdf 